\title{
Resurrection of vitamin D deficiency and rickets
}

\author{
Michael F. Holick
}

Department of Medicine, Section of Endocrinology, Nutrition, and Diabetes, and Vitamin D, Skin and Bone Research Laboratory, Boston University Medical Center, Boston, Massachusetts, USA.

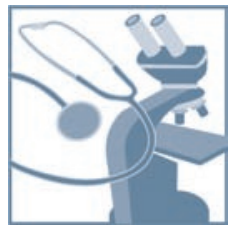

The epidemic scourge of rickets in the 19th century was caused by vitamin $D$ deficiency due to inadequate sun exposure and resulted in growth retardation, muscle weakness, skeletal deformities, hypocalcemia, tetany, and seizures. The encouragement of sensible sun exposure and the fortification of milk with vitamin $D$ resulted in almost complete eradication of the disease. Vitamin $D$ (where $D$ represents $D_{2}$ or $D_{3}$ ) is biologically inert and metabolized in the liver to 25 -hydroxyvitamin $\mathrm{D}[25(\mathrm{OH}) \mathrm{D}]$, the major circulating form of vitamin $\mathrm{D}$ that is used to determine vitamin $\mathrm{D}$ status. $25(\mathrm{OH}) \mathrm{D}$ is activated in the kidneys to 1,25 -dihydroxyvitamin $\mathrm{D}\left[1,25(\mathrm{OH})_{2} \mathrm{D}\right]$, which regulates calcium, phosphorus, and bone metabolism. Vitamin D deficiency has again become an epidemic in children, and rickets has become a global health issue. In addition to vitamin $\mathrm{D}$ deficiency, calcium deficiency and acquired and inherited disorders of vitamin $\mathrm{D}$, calcium, and phosphorus metabolism cause rickets. This review summarizes the role of vitamin $\mathrm{D}$ in the prevention of rickets and its importance in the overall health and welfare of infants and children.

\section{Historical perspective}

In the mid-1600s, most children who lived in the crowded and polluted industrialized cities of northern Europe developed a severe bone-deforming disease that was characterized by growth retardation, enlargement of the epiphyses of the long bones, deformities of the legs, bending of the spine, knobby projections of the ribcage, and weak and toneless muscles $(1,2)$ (Figure 1). In the latter part of the 19th century, autopsy studies done in Boston and Leiden, The Netherlands, showed that $80-90 \%$ of children had rickets.

In 1822, Sniadecki (3) recognized the importance of sun exposure for the prevention and cure of rickets. Palm (4) extended these observations in 1890 and promoted systemic use of sun baths to prevent rickets. In 1919, Huldschinski $(5,6)$ found that exposing children to radiation from a sun quartz lamp (mercury arc lamp) or carbon arc lamp for one hour 3 times a week was effective in treating rickets, as demonstrated by a marked increase in the mineralization of the skeleton, especially the ends of the long bones, evident in the child's $\mathrm{x}$-ray (Figure 2). A similar group of children not exposed to UV radiation showed no cure or only a slight improvement (6). He concluded that exposure to UV radiation was an "infallible remedy" against all forms of rickets in children. Two years later, Hess and Unger (7) exposed 7 rachitic children in New York City to varying periods of sunshine and reported marked improvement in the rickets of each child as evidenced by calcification of the epiphyses.

In 1918, Mellanby et al. (8) prevented rickets in puppies with cod liver oil. McCollum et al. (9) called this new nutritional factor vitamin D. Hess and Weinstock (10) and Steenbock and Black (11) observed that UV irradiation of various foods and oils imparted antirachitic activity. This led to enhancement of the antirachitic activity of milk by exposing milk to UV radiation or feeding cows UV-irradi-

Nonstandard abbreviations used: 1-OHase, 25-hydroxyvitamin D-1 $\alpha$-hydroxylase; $1,25(\mathrm{OH})_{2} \mathrm{D}, 1,25$-dihydroxyvitamin D; $25(\mathrm{OH}) \mathrm{D}, 25$-hydroxyvitamin D; DBP, vitamin D-binding protein; FGF23, fibroblast growth factor 23; PHEX, phosphate-regulating endopeptidase homolog, X-linked; PTH, parathyroid hormone; RANKL, receptor activator of NF- $\kappa B$ ligand; RXR, retinoic acid $X$ receptor; $S P F$, sun protection factor; UVB, ultraviolet B; VDR, vitamin D receptor; VDRE, vitamin D-responsive element. Conflict of interest: The author has declared that no conflict of interest exists. Citation for this article: J. Clin. Invest. 116:2062-2072 (2006). doi:10.1172/JCI29449. ated yeast. Once vitamin D was structurally identified and chemically synthesized inexpensively from yeast, it was directly added to milk at a standard of $400 \mathrm{IU}(1 \mathrm{IU}=25 \mathrm{ng})$ per quart $(12,13)$. It was thought that the vitamin D obtained from irradiated yeast was the same vitamin D that was produced in the skin. However, when it was observed that vitamin D from irradiated yeast had little antirachitic activity in chickens, whereas cod liver oil was effective, it was concluded that the vitamin D produced in the skin must be different (14). Vitamin D was isolated and identified from pig skin and shown to originate from 7-dehydrocholesterol $(1,2,14)$. To distinguish the two vitamin Ds, the vitamin $D$ from yeast was called vitamin $D_{2}$ and the one from pig and human skin vitamin $\mathrm{D}_{3}(1,2)$.

\section{Photobiology of vitamin $\mathbf{D}_{\mathbf{3}}$}

Sunlight was recommended as a therapeutic method to prevent rickets in infants, and a detailed description was published in the United States Children's Bureau Folder in $1931(13,14)$. It was recognized that in the temperate zone, sunlight was feeble in its antirachitic properties in the winter, and thus, it was recommended that children be exposed to UV radiation from a mercury arc or carbon arc lamp in the winter $(5,6,13,14)$ (Figure 2). During exposure to sunlight, the ultraviolet B (UVB) radiation (290-315 $\mathrm{nm}$ ) is absorbed by 7-dehydrocholesterol in the skin to form previtamin $\mathrm{D}_{3}(1,15)$. Previtamin $\mathrm{D}_{3}(1,15)$ is inherently unstable and rapidly converts by a temperature-dependent process to vitamin $\mathrm{D}_{3}$ (Figure 3). Once formed, it is ejected out of the skin cell into the extracellular space, where it is drawn into the dermal capillary bed by the vitamin D-binding protein (DBP) (1).

The efficiency of vitamin $\mathrm{D}_{3}$ synthesis in the skin is dependent on the number of UVB photons that penetrate into the epidermis. An increase in skin melanin pigmentation (16) and the topical application of a sunscreen (17), both of which efficiently absorb UVB photons, can markedly diminish by more than $90 \%$ the production of vitamin $\mathrm{D}_{3}$. Excessive exposure to sunlight cannot cause vitamin $\mathrm{D}$ intoxication because sunlight destroys any excess vitamin $\mathrm{D}_{3}$ produced in the skin $(18,19)$. Most UVB photons from the sun are absorbed by stratospheric ozone. An increase in the sun's zenith angle results in an increased path length for the UVB photons to travel, and this explains why at higher latitudes (above 

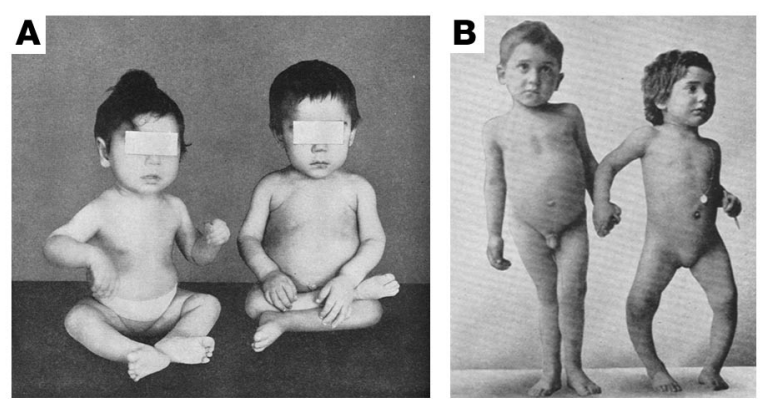

Figure 1

Skeletal deformities observed in rickets. (A) Photograph from the 1930s of a sister (left) and brother (right), aged 10 months and 2.5 years, respectively, showing enlargement of the ends of the bones at the wrist, carpopedal spasm, and a typical "Taylorwise" posture of rickets. (B) The same brother and sister 4 years later, with classic knockknees and bow legs, growth retardation, and other skeletal deformities. Reproduced from ref. 14.

$\sim 35^{\circ}$ latitude), very little, if any, vitamin $\mathrm{D}_{3}$ is produced in the skin from November through March $(19,20)$.

\section{Vitamin D metabolism and its role in calcium and phosphorus metabolism}

Vitamin $\mathrm{D}_{2}$ and vitamin $\mathrm{D}_{3}$ (D represents either $\mathrm{D}_{2}$ or $\mathrm{D}_{3}$ ) derived from supplements, fortified foods, and fish ingested from the diet (Table 1) are incorporated into chylomicrons and absorbed into the lymphatic system. From here they enter the circulation, where they are bound to the DBP and lipoproteins (1, 20-22). Vitamin D is released from DBP to the liver and undergoes a hydroxylation on C-25 by the vitamin D-25-hydroxylases (25-OHase; also known as CYP27A1, CYP3A4, CYP2R1, CYP2J3) to 25-hydroxyvitamin D $[25(\mathrm{OH}) \mathrm{D}](20-22)$ (Figure 3). $25(\mathrm{OH}) \mathrm{D}$ is the major circulating form of vitamin $\mathrm{D}$ that is measured to determine a person's vitamin D status because it has a half-life in the circulation of 2 weeks and it correlates with secondary hyperparathyroidism, rickets, and osteomalacia $(20,22-24) .25(\mathrm{OH}) \mathrm{D}$ is bound to DBP, and this complex binds to megalin on the plasma membrane of the renal tubule cell and is transported into the cell $(20,22)$. Once inside, $25(\mathrm{OH}) \mathrm{D}$ is released and is converted in the mitochondria by the 25-hydroxyvitamin D-1 $\alpha$-hydroxylase [1-OHase; also known as CYP27B1] to form 1,25 -dihydroxyvitamin $\mathrm{D}\left[1,25(\mathrm{OH})_{2} \mathrm{D}\right] \cdot 1,25(\mathrm{OH})_{2} \mathrm{D}$ is the biologically active form of vitamin $\mathrm{D}$ responsible for maintaining calcium and phosphorus homeostasis. It accomplishes this by interacting with its nuclear receptor, the vitamin $\mathrm{D}$ receptor (VDR) in the small intestinal cells $(22,25)$. The $1,25(\mathrm{OH})_{2} \mathrm{D}-\mathrm{VDR}$ structure complexes with retinoic acid $\mathrm{X}$ receptor $(\mathrm{RXR})$ in the nucleus. The $1,25(\mathrm{OH})_{2} \mathrm{D}-\mathrm{VDR}-\mathrm{RXR}$ complex binds to the vitamin D-responsive element (VDRE) for the epithelial calcium channel $(22,25)$. The increased expression of the calcium channel permits more calcium to enter the cell, where the vitamin D-dependent calcium-binding protein calbindin $9 \mathrm{~K}$ helps calcium's translocation into the bloodstream. $1,25(\mathrm{OH})_{2} \mathrm{D}$ also enhances phosphorus absorption in the small intestine $(1,22,25)$.

When dietary calcium is inadequate, vitamin D helps maintain calcium homeostasis by interacting with the VDR in osteoblasts to induce the expression of the plasma membrane protein receptor activator of NF-KB ligand (RANKL). The RANK on the plasma membrane of preosteoclasts binds RANKL, which induces the preosteoclast to become a mature osteoclast $(20,22,26)$. The mature osteoclast releases hydrochloric acid and collagenases to dissolve bone and release its precious calcium and phosphorus stores into the circulation. Thus, the major physiologic function of vitamin $\mathrm{D}$ is to maintain serum calcium and phosphorus levels within the normal physiologic range to support most metabolic functions, neuromuscular transmission, and bone mineralization (1, 20, 22, 24) (Figure 3).

\section{Vitamin D and calcium deficiencies as a cause of rickets}

Vitamin D deficiency is the most common cause of rickets. Vitamin $\mathrm{D}$ deficiency prevents the efficient absorption of dietary calcium and phosphorus. In a vitamin D-deficient state, only $10-15 \%$ of dietary calcium and $50-60 \%$ of dietary phosphorus are absorbed. The poor absorption of calcium causes a decrease in serum-ionized calcium levels. This is immediately recognized by the calcium sensor in the parathyroid glands, resulting in an increase in the expression, synthesis, and secretion of parathyroid hormone (PTH) $(1,20,22$, 27). PTH conserves calcium by increasing tubular reabsorption of calcium in both the proximal and distal convoluted tubules. PTH, like $1,25(\mathrm{OH})_{2} \mathrm{D}$, enhances the expression of RANKL on osteoblasts to increase the production of mature osteoclasts to mobilize calcium stores from the skeleton. PTH also decreases phosphorus reabsorption in the kidney, causing loss of phosphorus into the urine (Figure 4). The serum calcium level is usually normal in a vitamin D-deficient infant or child. However, the serum phosphorus level is low, and thus there is inadequate calcium-phosphorus product, which is necessary to mineralize the osteoid laid down by osteoblasts $(1,20,22,24,28)$ (Figure 4). Thus, typically, infants with vitamin $\mathrm{D}$-deficiency rickets have a normal serum calcium level, low normal or low fasting serum phosphorus levels, elevated alkaline phosphatase levels, and low $25(\mathrm{OH}) \mathrm{D}$ levels $(<15 \mathrm{ng} / \mathrm{ml})$ $(23,28-31)$ (Table 2$)$. The secondary hyperparathyroidism stimulates the kidneys to produce $1,25(\mathrm{OH})_{2} \mathrm{D}$, and thus, $1,25(\mathrm{OH})_{2} \mathrm{D}$ levels are normal or often elevated, which is why the measurement of $1,25(\mathrm{OH})_{2} \mathrm{D}$ is of no value in determining a state of vitamin $\mathrm{D}$ deficiency (24). Only when the calcium stores in the skeleton are totally depleted will the infant or child become hypocalcemic.

Vitamin D deficiency causes global poor mineralization of the skeleton. Clinical and radiological bone manifestations predominate in areas of rapid bone growth, including the long bone epiphyses and the costochondral junctions (5, 6, 12-14, 30-32). This is why rickets is mostly observed before 18 months of age, with maximum frequency between the ages of 4 and 12 months. Skeletal deformities are usually a result of long-standing rickets.
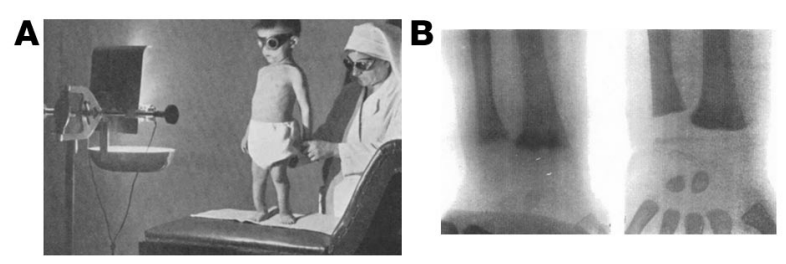

\section{Figure 2}

UV radiation therapy for rickets. (A) Photograph from the 1920s of a child with rickets being exposed to UV radiation. (B) Radiographs demonstrating florid rickets of the hand and wrist (left) and the same wrist and hand taken after treatment with 1 hour UV radiation 2 times a week for 8 weeks. Note mineralization of the carpal bones and epiphyseal plates (right). Reproduced from ref. 126. 


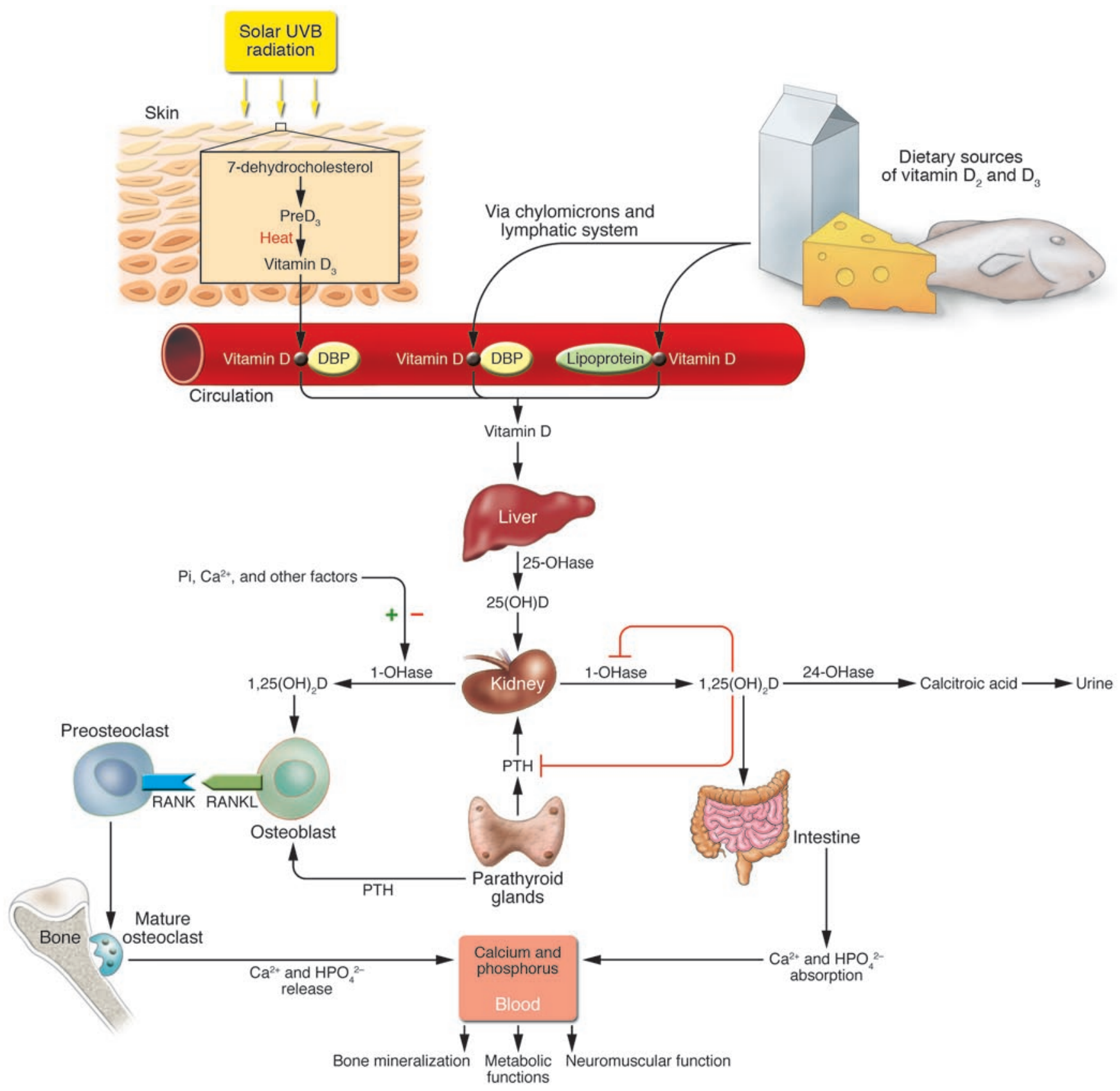

Figure 3

The photoproduction and metabolism of vitamin $\mathrm{D}$ and the various biologic effects of $1,25(\mathrm{OH})_{2} \mathrm{D}$ on calcium, phosphorus, and bone metabolism. Vitamin $D$ is either produced in the skin by exposure to UVB radiation or is ingested in the diet. Vitamin $D\left(D\right.$ represents vitamin $D_{2}$ or vitamin $\left.D_{3}\right)$ is converted by the vitamin D-25-hydroxylase $\left(25-\mathrm{OH}\right.$ ase) in the liver to $25(\mathrm{OH}) \mathrm{D} .25(\mathrm{OH}) \mathrm{D}$ is converted in the kidneys by $1-\mathrm{OH}$ ase to $1,25(\mathrm{OH})_{2} \mathrm{D}$. Once formed, $1,25(\mathrm{OH})_{2} \mathrm{D}$ enhances intestinal calcium and phosphorus absorption and stimulates the expression of RANKL on the osteoblasts to interact with its receptor RANK on preosteoclasts to induce mature osteoclastic activity, which releases calcium and phosphorus $\left(\mathrm{HPO}_{4}{ }^{2-}\right)$. In addition, $1,25(\mathrm{OH})_{2} \mathrm{D}$ inhibits the renal 1-OHase and stimulates the expression of the renal 25(OH)D-24-hydroxylase (24-OHase). The induction of the 24-OHase results in the destruction of $1,25(\mathrm{OH})_{2} \mathrm{D}$ into a water-soluble inactive metabolite calcitroic acid. Pre $\mathrm{D}_{3}$, previtamin $\mathrm{D}$.

Hypertrophy of the costochondral junctions leads to beading and the classic rachitic rosary that progresses with involution of the ribs and protrusion of the sternum (pigeon chest) and recession of the costochondral junctions and traverse depressions causing Harrison's groove. Once the child begins to stand, gravity pushing on the lower limbs results in either inward (genu valgum) or out- ward (genu varum) tibial and femoral bowing. Muscle pull can also cause bone deformities in both upper and lower limbs even before the infant begins to walk. Muscle traction on the softened ribcage is responsible for the chest deformation, leading to pectus carinatum, thoracic asymmetry, and widening of the thoracic base. Softening of the occipital area (rachitic craniotabes), enlarged sutures and 
Table 1

Dietary sources of vitamin D

$\begin{array}{lc}\text { Source } & \text { Vitamin D content } \\ \text { Fortified milk } & 100 \mathrm{IU} / 8 \mathrm{oz} \\ \text { Fortified orange juice } & 100 \mathrm{IU} / 8 \mathrm{oz} \\ \text { Infant formulas } & 100 \mathrm{IU} / 8 \mathrm{oz} \\ \text { Fortified yogurts } & 100 \mathrm{IU} / 8 \mathrm{oz} \\ \text { Fortified butter } & 56 \mathrm{IU} / 3.5 \mathrm{oz} \\ \text { Fortified margarine } & 429 \mathrm{IU} / 3.5 \mathrm{oz} \\ \text { Fortified cheeses } & 100 \mathrm{IU} / 3 \mathrm{oz} \\ \text { Fortified breakfast cereals } & \sim 100 \mathrm{IU} / \mathrm{serving} \\ \text { Egg yolk } & 20 \mathrm{IU} / \mathrm{yolk} \\ \text { Shiitake mushrooms, fresh } & 100 \mathrm{IU} / 3.5 \mathrm{oz} \\ \text { Tuna, canned } & 236 \mathrm{IU} / 3.5 \mathrm{oz} \\ \text { Mackerel, canned } & \sim 250 \mathrm{IU} / 3.5 \mathrm{oz} \\ \text { Sardines, canned } & \sim 300 \mathrm{IU} / 3.5 \mathrm{oz} \\ \text { Salmon, canned } & \sim 300-600 \mathrm{IU} / 3.5 \mathrm{oz} \\ \text { Salmon, fresh } & 400-500 \mathrm{IU} / 3.5 \mathrm{oz} \\ \text { Shiitake mushrooms, sun-dried } & 1,600 \mathrm{IU} / 3.5 \mathrm{oz} \\ \text { Drisdol (vitamin } \mathrm{D}_{2} \text { ) liquid } & 8,000 \mathrm{IU} / \mathrm{cc} \\ \text { Cod liver oil } & 400 \mathrm{IU} / \mathrm{tsp}\end{array}$

fontanelles, delayed closing of fontanelles, and occipital or parietal flattening can be observed $(5,6,12,13,30-32)$ (Figure 1). Tooth development is impaired, with delayed eruption, enamel hypoplasia, and early dental caries (12-14). The pelvic bone structure is flattened in rachitic children. Because of the high incidence of infant and maternal morbidity and mortality in rachitic women, children were often delivered by Caesarian section $(1,2)$.

Extraskeletal manifestations associated with hypocalcemia lead to tetany, seizures, laryngospasm, and hypocalcemic myocardiopathy and death $(6,12-14,32)$. Often there is delayed motor development with hypotonia in the absence of hypocalcemia. Weakness of the thoracic muscles together with softening of the ribcage results in defective ventilation with respiratory obstruction and infection. In older children and adolescents, symptoms similar to those observed in adult osteomalacia, including bone pain, waddling gait, and fatigue, may be present (12-14, 24, 30-32). Hematologic disorders are often observed in common rickets, including hypochromic anemia and the rare Von Jacksch-Luzet syndrome. This syndrome is associated with severe anemia and a profile of chronic myeloid leukemia with erythroblastosis, leukocytosis, myelocytosis, and possible myeloblastosis. The spleen and liver can be enlarged as a result of extramedullary hematopoiesis. The bone marrow is hypoplastic. This syndrome is often cured with simple vitamin D therapy (31).

Severe calcium deficiency can lead to rickets in much the same way as vitamin $\mathrm{D}$ deficiency (32-35). Very low dietary calcium intake leads to decreased ionized calcium and secondary hyperparathyroidism. This causes a mineralization defect in the skeleton that results in growth retardation and many of the skeletal manifestations seen in vitamin D deficiency, but these are of greater severity due to the hypocalcemia (31-35) (Figure 4).

Inadequate calcium intake during the 3 rd trimester of pregnancy can cause a serious calcium deficit in the fetal skeleton that is rapidly being mineralized during the last 7 weeks in utero. Typically at 28 weeks, $100 \mathrm{mg} / \mathrm{d}$ of calcium is being deposited in the skeleton, whereas at 35 weeks $350 \mathrm{mg} / \mathrm{d}$ is being deposited (30, 31,
36). Therefore, mother's milk containing 240-340 mg/l of calcium is unable to meet the demands of postnatal accretion rates of a preterm infant $(30,31)$.

Young children and adolescents, especially non-white individuals, on a strict vegetarian diet or a diet that is high in phytate, which binds calcium, can also be calcium deficient, which leads to rickets (33-35). This, in combination with vitamin D deficiency, is often the precipitating cause of rickets in children of Middle Eastern descent living in Great Britain and African American children in the United States (32-35).

The calcium deficiency and associated secondary hyperparathyroidism increase the requirement for vitamin $\mathrm{D}$, since the vitamin $\mathrm{D}$ is rapidly metabolized to $1,25(\mathrm{OH})_{2} \mathrm{D}$. The combination of calcium deficiency and vitamin $\mathrm{D}$ deficiency accelerates and makes more severe the skeletal abnormalities and hypocalcemia.

\section{Prevalence of subclinical vitamin D deficiency}

Severe chronic vitamin D deficiency [25(OH)D level less than 15 $\mathrm{ng} / \mathrm{ml}$ l leads to overt skeletal abnormalities in children that is typically defined as rickets $(23,30-32)$. However, there is a large number of infants, children, and adolescents who are vitamin D insufficient but have no apparent skeletal or calcium metabolism abnormalities (Table 2). We observed that of 40 "healthy" mother-infant pairs that were predominantly non-white, $73 \%$ of mothers and $80 \%$ infants had $25(\mathrm{OH}) \mathrm{D}$ levels of less than $20 \mathrm{ng} / \mathrm{ml}$ despite the fact that $80 \%$ of the mothers took a daily prenatal multivitamin that contained 400 IU of vitamin D (37). Sullivan et al. (38) reported that $48 \%$ of white girls aged 9-11 years in Maine had 25(OH)D levels less than $20 \mathrm{ng} / \mathrm{ml}$ at the end of the winter and $17 \%$ remained vitamin D deficient at the end of the summer due either to avoiding sun exposure or always wearing sun protection. Forty-two percent of adolescent African American and Hispanic children had 25(OH)D levels less than $20 \mathrm{ng} / \mathrm{ml}$ in Boston (39), which is consistent with the observation by the Centers for Disease Control that $48 \%$ of African American women aged 15-49 years throughout the entire United States had 25(OH)D levels of less than $15 \mathrm{ng} / \mathrm{ml}$ at the end of the winter (40). Similar observations have been made in Canada and Europe, where few foods are fortified with vitamin $\mathrm{D}$ and the high latitude limits vitamin D production in the skin (41-45). Remarkably, in the sunniest areas of the world, rickets is a major health problem. Because of the practice of purdah or wearing a burka $(45,46)$, avoidance of exposure of any skin to sunlight, and the fact that few foods are fortified with vitamin D, upward of $35-80 \%$ of children in Saudi Arabia (46, 47), India (48), Turkey (29), New Zealand (49), Israel (50), Egypt (51), Hong Kong (52), China (53), Libya (54), Lebanon (55), Spain (56), Australia (57), San Diego, California (58), and the southeastern United States (59) are vitamin D deficient. When the deficiency occurs during fetal life, there is data to suggest that this may cause an increased risk of hip fractures and bone loss later in life $(56,60,61)$. Subclinical vitamin D deficiency in neonates is associated with a normal serum calcium level, low 25(OH)D concentration (typically between 10 and $20 \mathrm{ng} / \mathrm{ml}$ ), and elevated serum PTH, 1,25(OH $)_{2} \mathrm{D}$ and alkaline phosphatase levels (30-32).

\section{Inherited causes of rickets}

Once it was recognized that vitamin D must be metabolized in the liver and kidneys before it can carry out its biologic effects on calcium, phosphorus, and bone metabolism, it was hypothesized that a defect in the hepatic 25-hydroxylation or renal $1 \alpha$-hydroxylation steps would lead to an inability to activate vitamin D, thus causing 


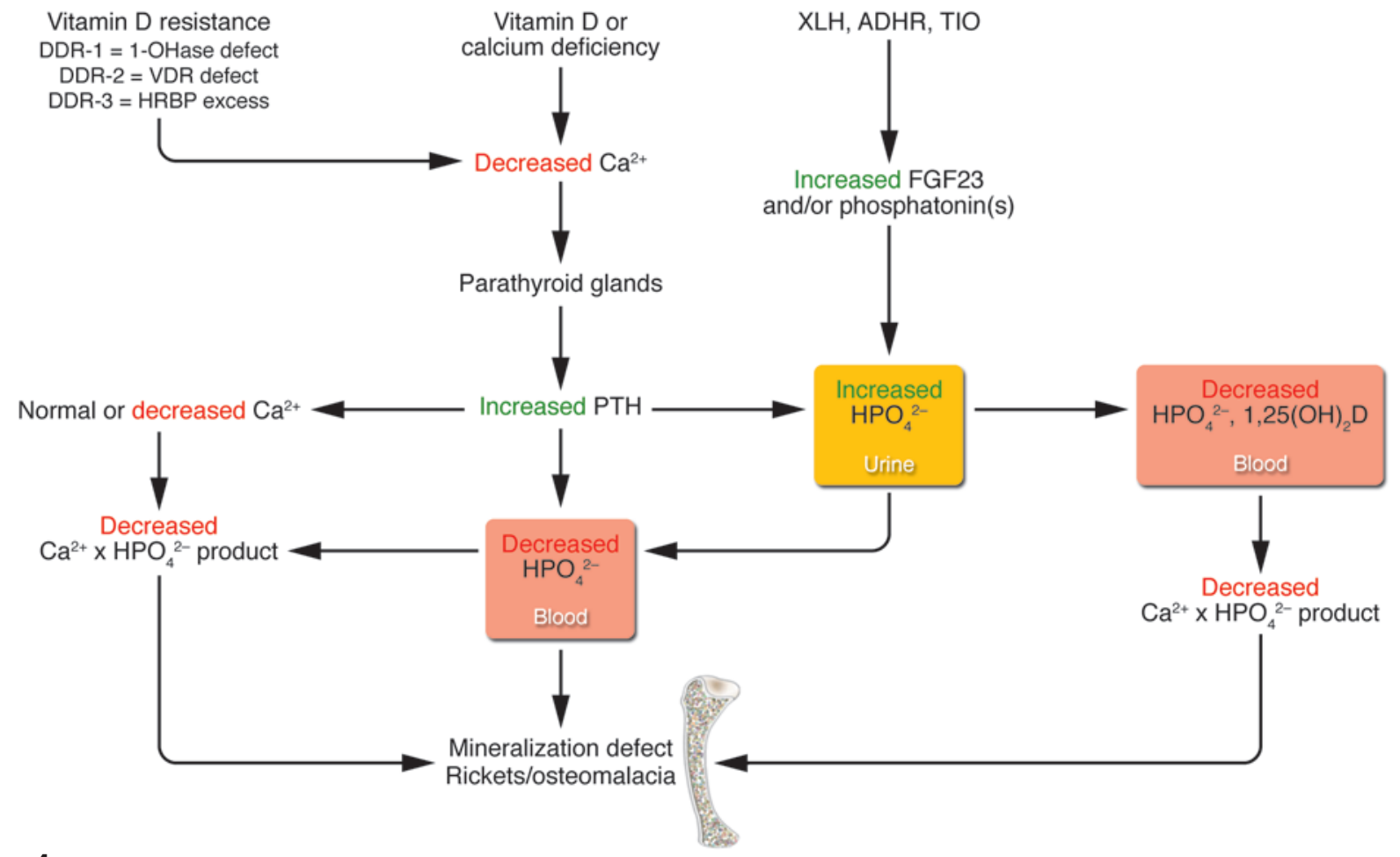

\section{Figure 4}

Biochemical changes in calcium and phosphorus metabolism due to vitamin D or calcium deficiency, vitamin D-resistant syndromes, or hypophosphatemic syndromes that cause rickets or osteomalacia. Vitamin D and/or calcium deficiency leads to a decrease in the level of ionized calcium $\left(\mathrm{Ca}^{2+}\right)$, resulting in an increase in PTH. PTH increases tubular reabsorption of calcium to correct the serum calcium into the normal range. However, in severe calcium and vitamin D deficiency, the serum calcium is below normal. In addition, PTH causes phosphorus loss via the urine, resulting in a decrease in serum $\mathrm{HPO}_{4}{ }^{2-}$. An inadequate calcium-phosphorus product $\left(\mathrm{Ca}^{+2} \times \mathrm{HPO}_{4}{ }^{2-}\right)$ leads to a defect in bone mineralization that causes rickets in children and osteomalacia in adults. There are various inherited and acquired disorders that can disrupt calcium and phosphorus metabolism that can also result in defective mineralization of the skeleton. There are 3 inherited syndromes that cause vitamin $D$ resistance. Vitamin D-dependent rickets type 1 (DDR-1) is due to a mutation of the 1-OHase. A mutation of the VDR gene results in an ineffective recognition of $1,25(\mathrm{OH})_{2} \mathrm{D}$, causing DDR-2. A genetic defect that results in the overproduction of hormone response element-binding protein (HRBP) eliminates the interaction of $1,25(\mathrm{OH})_{2} \mathrm{D}$ with its VDR, resulting in DDR-3. There are also inherited and acquired disorders that cause severe hypophosphatemia and decrease renal production of $1,25(\mathrm{OH})_{2} \mathrm{D}$. The acquired disorders X-linked hypophosphatemic rickets $(\mathrm{XLH})$ and autosomal dominant hypophosphatemic rickets (ADHR) are caused by the increased production or decreased destruction, respectively, of phosphatonins that include FGF23. Tumor-induced osteomalacia (TIO) is caused by the tumor's production of FGF23, which results in phosphaturia and a decrease in the renal production of $1,25(\mathrm{OH})_{2} \mathrm{D}$.

a vitamin $\mathrm{D}$ deficiency-like state that was resistant to physiologic doses of vitamin D (Figure 4). There is only one documented case of $25-O H a s e-d e f i c i e n c y$ rickets (62). The most likely reason why more cases are not reported is that there are at least 4 different enzymes that have the ability to convert vitamin $\mathrm{D}$ to $25(\mathrm{OH}) \mathrm{D}(63)$.

Since vitamin D undergoes its final activation in the kidneys, several studies of individuals with "vitamin D-resistant" diseases causing rickets in which patients were evaluated for a defect in the metabolism of $25(\mathrm{OH}) \mathrm{D}$ to $1,25(\mathrm{OH})_{2} \mathrm{D}$ have been reported. Pseudovitamin D-deficiency rickets (also known as hereditary, vitamin D-dependent rickets type 1 ), a rare hereditary disorder, was found to be associated with very low or undetectable levels of $1,25(\mathrm{OH})_{2} \mathrm{D}$ in the circulation (64). These children responded to orally administered $1,25(\mathrm{OH})_{2} \mathrm{D}_{3}(64)$. The cloning of the renal 1-OHase enzyme led to the identification of a multitude of point mutations of the CYP27B1 gene, which result in either a poorly functional 1-OHase or the complete absence of 1-OHase activity (65).

Several investigators reported children with severe rickets who often had alopecia and extremely elevated levels of $1,25(\mathrm{OH})_{2} \mathrm{D}$
$(65,66)$. Some children with this disease, vitamin D-resistant rickets (hereditary, vitamin D-dependent rickets type 2), responded to pharmacologic doses of vitamin D or $1,25(\mathrm{OH})_{2} \mathrm{D}_{3}$, while others did not $(66,67)$. Point mutations in the VDR gene are responsible for the vitamin D resistance. Chen et al. (68) reported a new form of vitamin D resistance, hereditary vitamin D-dependent rickets type 3 , caused by the abnormal expression of a hormone response element-binding protein (HRBP) that binds to the VDRE and therefore prevents the $1,25(\mathrm{OH})_{2} \mathrm{D}-\mathrm{VDR}-\mathrm{RXR}$ complex from binding to its responsive element. This patient had normal VDR expression and was completely resistant to $1,25(\mathrm{OH})_{2} \mathrm{D}_{3}$ action. Children with these vitamin D-resistance syndromes often suffer from severe bone deformities and more marked hypocalcemia than children with vitamin $\mathrm{D}$-deficiency rickets. Treatment depends on the cause and severity of the vitamin D resistance. Children have responded to pharmacologic doses of vitamin $\mathrm{D}$, physiologic and pharmacologic doses of $1,25(\mathrm{OH})_{2} \mathrm{D}_{3}$ and its analog $1 \alpha$-hydroxyvitamin $\mathrm{D}_{3}$, as well as intravenous infusions of calcium and phosphorus $(30,64,66-69)$. 


\section{Table 2}

Vitamin D status and associated biochemistries: serum levels of $25(\mathrm{OH}) \mathrm{D}, 1,25(\mathrm{OH})_{2} \mathrm{D}, \mathrm{Ca}, \mathrm{HPO}_{4}{ }^{2-}$, alkaline phosphatase (Alk. phos.), PTH, and FGF23

\begin{tabular}{|c|c|c|c|c|c|c|c|c|}
\hline & $25(\mathrm{OH}) \mathrm{D}, \mathrm{ng} / \mathrm{ml}$ & 1,25(OH)2D & $\mathrm{Ca}$ & $\mathrm{HPO}_{4}{ }^{2-}$ & Alk. phos. & PTH & FGF23 & Skeletal disease \\
\hline Vitamin D deficiency & $<20$ & $\uparrow$ & $\downarrow N L$ & $\downarrow$ & $\uparrow$ & $\uparrow$ & $N L$ & Rickets/osteomalacia \\
\hline Vitamin D insufficiency & $21-29$ & $\uparrow$ or NL & NL & NL & $\uparrow$ or NL & $\uparrow$ or NL & NL & $\downarrow \mathrm{BMD}$ \\
\hline Vitamin D sufficiency & $>30$ & $\mathrm{NL}$ & NL & NL & $\mathrm{NL}$ & $\mathrm{NL}$ & $\mathrm{NL}$ & None \\
\hline XLH & $\mathrm{NL}$ & $\downarrow$ & NL & $\downarrow \downarrow$ & $\uparrow$ & NL & $\uparrow$ or NL & Rickets \\
\hline ADHR & NL & $\downarrow$ & NL & $\downarrow \downarrow$ & $\uparrow$ & NL & $\uparrow \uparrow$ & Rickets \\
\hline TIO & NL & $\downarrow$ & NL & $\downarrow \downarrow$ & $\uparrow$ & NL & $\uparrow \uparrow$ & Rickets \\
\hline
\end{tabular}

The upward-pointing arrows ( $\uparrow$ and $\uparrow \uparrow$ ) indicate that the level is moderately or markedly above the normal range, respectively, and the downward-pointing arrows $(\downarrow$ and $\downarrow \downarrow)$ indicate that the serum level is moderately or markedly below the normal range, respectively. NL represents levels within the normal range. BMD, bone mineral density; XLH, X-linked hypophosphatemic rickets; ADHR, autosomal dominant hypophosphatemic rickets; TIO, tumorinduced osteomalacia.

\section{Inherited and acquired hypophosphatemic rickets}

These disorders are characterized by hypophosphatemia, decreased reabsorption of phosphorus by the renal tubule, decreased absorption of calcium and phosphorus from the gastrointestinal tract, and varying degrees of rickets or osteomalacia $(70,71)$. Patients often have normal or reduced serum levels of $1,25(\mathrm{OH})_{2} \mathrm{D}$, which is considered to be abnormal, since hypophosphatemia causes an increase in serum $1,25(\mathrm{OH})_{2} \mathrm{D}$ levels because it enhances the renal production of $1,25(\mathrm{OH})_{2} \mathrm{D}(70,72)$. Originally it was thought that hypophosphatemic disorders were caused by a defect in a renal phosphate transport protein. However, recent evidence suggests that other factors of bone origin participate in maintaining phosphorus homeostasis, including fibroblast growth factor 23 (FGF23), matrix extracellular phosphoglycoprotein, and frizzled-related protein 4 . These factors are collectively known as phosphatonins (73). When FGF23 is elevated, it causes an internalization of the sodium phosphate cotransporter in both the kidneys and intestine, thereby causing phosphaturia and decreased intestinal phosphate absorption (74). It also inhibits CYP27B1 activity. Patients with autosomal dominant hypophosphatemic rickets (ADHR) have a mutation in the FGF23 gene that prevents or reduces FGF23 metabolic breakdown, leading to elevated FGF23 levels $(70,75)$. Tumor-induced osteomalacia is caused by a small tumor that is often benign and secretes FGF23 $(70,71,73,74)$. The exact cause of X-linked hypophosphatemic rickets is less well understood. It has been linked to a mutation of the phosphate regulating endopeptidase homolog, $X$-linked (PHEX) gene. Loss of its expression causes overexpression of FGF23 and possibly other phosphatonins in bone, leading to increased levels of circulating FGF23 (74).

Thus, hypophosphatemic rickets is caused by an inability to metabolize FGF23 or the excessive production of FGF23 (70, $71,73,74)$ (Figure 4). Intravenous phosphate delivery has been effective in treating rickets and osteomalacia $(70,71,76)$, and removal of the tumor is curative $(77,78)$. Treatment includes frequent oral phosphate administration, typically 250-500 mg up to 5 times a day, as well as twice daily oral delivery of $0.5-1.0$ $\mu \mathrm{g}$ of $1,25(\mathrm{OH})_{2} \mathrm{D}_{3}(70,71,76)$. Less frequent administration of higher doses of phosphate is to be discouraged, since the transient increase in serum phosphate causes a decrease in ionized calcium and an increase in PTH level and causes parathyroid glands to become hyperplastic and autonomous, which leads to tertiary hyperparathyroidism.

\section{Prevention and treatment of vitamin D- and calcium-deficiency rickets}

In the 1940s, the recommended intake of vitamin D for infants was $100 \mathrm{IU} / \mathrm{d}$ to prevent rickets (14). However, the current accepted recommendation to prevent rickets is a daily $400 \mathrm{IU}$ dose of vitamin $\mathrm{D}$ and adequate calcium intake $(32-35,79)$. Clinical trials in preterm infants (16 days of age) were randomized to daily vitamin D intakes of $200 \mathrm{IU}$ (90 IU/kg), $400 \mathrm{IU}$ (180 IU/kg), or $800 \mathrm{IU}$ $(360 \mathrm{IU} / \mathrm{kg}$ ) for up to one month. No radiological differences were observed between groups $(80)$. The $25(\mathrm{OH}) \mathrm{D}$ levels in the group receiving 200 IU vitamin D for $24-29$ days did not change, whereas the groups receiving $400 \mathrm{IU}$ and $800 \mathrm{IU}$ for the same period of time showed an increase in $25(\mathrm{OH}) \mathrm{D}$ levels of approximately $30 \%$. Similar studies also suggested that preterm infants' plasma $25(\mathrm{OH}) \mathrm{D}$ levels were maintained from early neonatal life to 3 months with administration of supplemental vitamin D of $400 \mathrm{IU} / \mathrm{d}$. No benefit in vitamin $\mathrm{D}$ status or forearm bone mineral density was observed at a higher dose of $900 \mathrm{IU} / \mathrm{d}(30,81)$. In Europe, the Nutrition Committee for the European Society of Pediatric Gastroenterology, Hepatology and Nutrition recommended a vitamin D intake of 800-1,600 IU/d (36). Mawer et al. (36) gave either 1,000 or 3,000 IU of vitamin $\mathrm{D}_{2}$ daily to low-birth-weight infants with a mean weight of $1.36 \mathrm{~kg}$ and found that the $25(\mathrm{OH}) \mathrm{D}$ level increased from a baseline of $6-10 \mathrm{ng} / \mathrm{ml}$ to a mean of $33 \mathrm{ng} / \mathrm{ml}$ in both dose groups after 7 weeks. They also observed that the $25(\mathrm{OH}) \mathrm{D}$ levels rapidly rose during the first week and began to plateau at 7 weeks at approximately $33 \mathrm{ng} / \mathrm{ml}$. Markestad et al. (23) treated children with $1,700-4,000 \mathrm{IU}$ vitamin $\mathrm{D}_{2}$ /day for up to 10 weeks and showed an average $25(\mathrm{OH}) \mathrm{D}$ level of approximately $30 \mathrm{ng} / \mathrm{ml}$ and correction of their biochemical and skeletal abnormalities. Premature neonates treated with $1,200 \mathrm{IU}$ vitamin $\mathrm{D}_{3}$ /day for 7 days raised their $25(\mathrm{OH}) \mathrm{D}$ level from $8 \mathrm{ng} / \mathrm{ml}$ to $18 \mathrm{ng} / \mathrm{ml}(81)$. Although it is not known what the minimum normal level of $25(\mathrm{OH}) \mathrm{D}$ should be for infants and neonates based on these observations, it is not unreasonable for the blood level to be at least $20 \mathrm{ng} / \mathrm{ml}$. However, since those studies showed that $25(\mathrm{OH}) \mathrm{D}$ levels reached a plateau at approximately $33 \mathrm{ng} / \mathrm{ml}$, this is likely the ideal healthy level for infants and children and is similar for adults $(23,24,30,36$, 81-84). To achieve a healthy 25(OH)D level of greater than $30 \mathrm{ng} / \mathrm{ml}$, infants require at least 400-1,000 IU of vitamin D/day depending on their 25(OH)D levels at birth.

Infants who are vitamin $\mathrm{D}$ deficient should not simply receive what is the recommended US adequate intake (200 IU/d) (85) or 
even $400 \mathrm{IU} / \mathrm{d}$ but rather should be aggressively treated with pharmacologic doses of vitamin D in order to build up the body stores of vitamin $\mathrm{D}$ and quickly correct the vitamin $\mathrm{D}$ deficiency. The best method to effectively treat and cure rickets is to give a total of 5-15 mg (200,000-600,000 IU) of vitamin $\mathrm{D}_{2}$ or vitamin $\mathrm{D}_{3}$ orally with adequate dietary calcium (86). These doses can be given safely either as a single-day therapy or as daily doses of 2,000-4,000 IU/d $(50-100 \mu \mathrm{g} / \mathrm{d})$ for $3-6$ months $(30,86,87)$. Typically there is rapid correction of both serum calcium and phosphorus levels within 6-10 days and normalization of PTH levels within 1-2 months. Alkaline phosphatase decline and healing of radiologic signs of rickets are observed within 3-6 months depending on the severity of the deficiency $(30,86)$. For those who may not comply with this regime, it is recommended that $5 \mathrm{mg}(200,000 \mathrm{IU})$ of vitamin D be given as a single oral dose, with a follow-up dose of $5 \mathrm{mg} 3$ months later. It is imperative to initiate therapy with large doses of vitamin $D$, since giving small daily doses of 200-400 IU/d will not restore adequate stores of vitamin $\mathrm{D}$ as rapidly as either a single large dose or daily doses that are 10- to 20-fold higher than the recommended adequate intake (AI) $(30,85,86,87)$. For infants and children who have fat malabsorption, including cystic fibrosis patients (88), it is recommended that subcutaneous or intramuscular administration be used. Alternatively, controlled exposure to sunlight or UV radiation from a commercial lamp is advisable $(5,6,12-14,30,33,88)$.

\section{Sunlight, UV irradiation, and neonatal and maternal vitamin D supplementation}

Regular and sensible sun exposure during the months of the year when vitamin D production is promoted is still the most physiologic way to prevent vitamin D deficiency in infants and young children $(1,24,80,89)$. Seasonal variations in serum $25(\mathrm{OH}) \mathrm{D}$ in children and adults is well documented, with levels reaching a peak in the middle of the summer and nadir at the end of the winter in both the Northern and Southern Hemispheres $(1,19,24$, 57,89 ). Since breast milk has very little, if any, vitamin D (usually no more than $25 \mathrm{IU} / \mathrm{l}$ ), it is usually inadequate in satisfying the infant's requirement $(85,87,90)$. Thus, if the infant is receiving nutrition solely from breast-feeding and if the mother is vitamin D deficient, the infant will become vitamin $\mathrm{D}$ deficient and will likely develop rickets $(30,37,90)$.

Neonates and young children who do not receive adequate vitamin D from their diet respond well to oral doses of 1,000-1,500 $\mathrm{IU} / \mathrm{d}$ all year up to the age of 2 and during the winter up to age 5 years without any sign of vitamin $\mathrm{D}$ intoxication (30). This prevention scheme has been very effective in Europe for at-risk infants who are exclusively breast-fed or who are too old to take formula (30). Prevention with lower daily doses of 400-500 IU/d is recommended for other breast-fed infants and for at-risk neonates and young infants receiving formula. The effect of providing mother or infant during lactation with supplements of $400 \mathrm{IU}$ of vitamin $\mathrm{D}$ showed that it is most effective to give the infant vitamin D supplementation daily. However, Hollis et al. (90) reported that giving lactating females 4,000 IU vitamin $\mathrm{D}_{3}$ daily provides adequate vitamin D in breast milk to satisfy the infant's requirement.

\section{Noncalcemic and nonskeletal consequences of vitamin $\mathbf{D}$ deficiency in children}

Children with vitamin D deficiency often suffer from severe muscle weakness with toneless and flabby legs (1, 2, 12-14, 30-32). It is now recognized that skeletal muscle has a VDR and that $1,25(\mathrm{OH})_{2} \mathrm{D}$ improves muscle function (91). Serum 25(OH)D levels above 30 $\mathrm{ng} / \mathrm{ml}$ maximize proximal muscle leg function in adults (92). It was observed in healthy adults that if the serum $25(\mathrm{OH}) \mathrm{D}$ was greater than $20 \mathrm{ng} / \mathrm{ml}$, there was a significant increase in lung function, with an average increase in forced expiratory volume of $176 \mathrm{ml}$ (93). Camargo et al. (94) reported a prospective study of maternal intake of vitamin D during pregnancy and observed that vitamin D deficiency was highly predictive of increased risk for asthma.

The VDR is present not only in tissues that regulate serum calcium, including the small intestine, bone cells, and kidney, but also in essentially all tissues and cells in the body, including brain, colon, breast, prostate, pancreas, heart, skin, skeletal muscle, monocytes, and activated $\mathrm{T}$ and $\mathrm{B}$ lymphocytes $(1,20-22,24)$. The first insight into the noncalcemic role of $1,25(\mathrm{OH})_{2} \mathrm{D}_{3}$ was observed when $1,25(\mathrm{OH})_{2} \mathrm{D}_{3}$ was incubated with mouse and human leukemic cells. $1,25(\mathrm{OH})_{2} \mathrm{D}_{3}$ inhibited leukemic cell proliferation and induced the cells to mature $(20-22,95,96)$. Many cancer cell lines and primary cancer cell cultures that posses a VDR demonstrate marked inhibition of growth and induction of maturation when exposed to $1,25(\mathrm{OH})_{2} \mathrm{D}_{3}$ or its active analogues $(1,20-22,24,96)$ (Figure 5). 1,25(OH)D does this by inducing cellular maturation, regulating the expression of $\mathrm{p} 21$ and $\mathrm{p} 27$ and apoptosis, and acting as an antiangiogenic factor $(20-22,24,95,96)$.

Living at higher latitudes and being prone to vitamin D deficiency increase risk of cancers of the colon, prostate, breast, ovary, esophagus, and several other tissues (1, 24, 97-99). It has been suggested that maintenance of a $25(\mathrm{OH}) \mathrm{D}$ level greater than 20 $\mathrm{ng} / \mathrm{ml}$ reduces risk of colon, prostate, breast, and ovarian cancer by as much as $30-50 \%(24,97-99)$. Although it is unknown whether vitamin D deficiency in utero and during infancy and childhood would imprint on the child for the rest of his or her life an increased risk of these deadly cancers, the recent observation that children exposed to the most sunlight had a $40 \%$ reduced risk of developing non-Hodgkin lymphoma (100) and increased survival from malignant melanoma (101) suggests that maintenance of adequate $25(\mathrm{OH}) \mathrm{D}$ levels throughout life may help reduce risk of many deadly cancers $(24,97-99,102)$.

Living above the $35^{\circ}$ latitude for the first 10 years of life imprints on a child for the rest of his or her life a $100 \%$ increased risk of developing multiple sclerosis no matter where they live thereafter $(24,103,104)$. Living at higher latitude and being prone to vitamin $\mathrm{D}$ deficiency increases risk of several other autoimmune diseases including type 1 diabetes and Crohn disease $(105,106)$. Children in Finland in the 1960s who received the recommended $2,000 \mathrm{IU}$ of vitamin D/day at least during the first year of life and followed for the next 31 years demonstrated a reduced risk of developing type 1 diabetes by $80 \%$ (105). Furthermore, children from the same cohort who were vitamin $\mathrm{D}$ deficient at one year of age had a 2.4-fold increased risk of developing type 1 diabetes. Vitamin D deficiency in utero and during the first year of life has also been linked to increased risk of type 1 diabetes (107). $1,25(\mathrm{OH})_{2} \mathrm{D}$ affects the immune system $(106,108)$, and, as pancreatic islet $\beta$ cells have a VDR, it also stimulates insulin secretion $(20-22,24)$ (Figure 5). Thus, hypovitaminosis D in children may increase their risk not only of type 2 diabetes but also insulin resistance and islet $\beta$ cell dysfunction (109).

Living at higher latitude and vitamin $\mathrm{D}$ deficiency are also associated with hypertension and cardiovascular heart disease (24, $110,111)$. Li et al. (112) reported that $1,25(\mathrm{OH})_{2} \mathrm{D}_{3}$ is an effective regulator of renin production, which controls blood pressure. A 


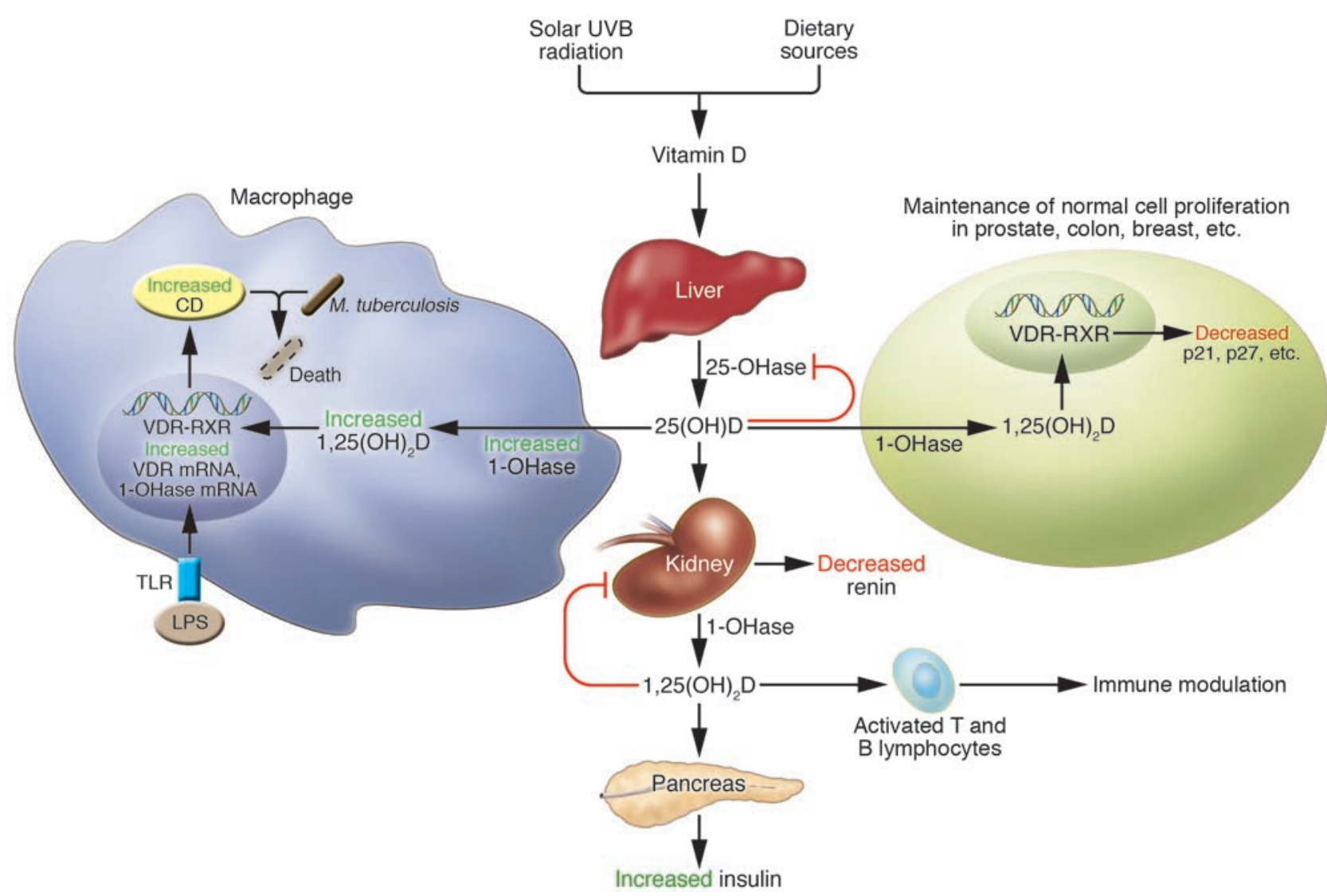

Figure 5

Noncalcemic functions of $1,25(\mathrm{OH})_{2} \mathrm{D}$. Vitamin $\mathrm{D}$ coming from the photoproduction of previtamin $\mathrm{D}$ or coming from the diet is converted in the liver to $25(\mathrm{OH}) \mathrm{D}$ by the vitamin $25-\mathrm{OH}$ ase. $25(\mathrm{OH}) \mathrm{D}$ is converted in the kidneys by $1-\mathrm{OH}$ ase. $1,25(\mathrm{OH})_{2} \mathrm{D}$ not only regulates calcium and phosphorus metabolism but can stimulate the pancreas to produce insulin and to downregulate the renal production of renin. $1,25(\mathrm{OH})_{2} \mathrm{D}$ also interacts with its nuclear receptor (VDR) in a wide variety of tissues and cells and helps maintain normal cell proliferation and differentiation. 25(OH)D can also be converted to $1,25(\mathrm{OH})_{2} \mathrm{D}$ in a wide variety of cells, including colon, prostate, and breast, for the autocrine production of $1,25(\mathrm{OH})_{2} \mathrm{D}$. It is believed that the autocrine production of $1,25(\mathrm{OH})_{2} \mathrm{D}$ is important for regulating cell growth and maturation, which decreases risk of the cell becoming malignant. $25(\mathrm{OH}) \mathrm{D}$ also is metabolized in macrophages by the $1-\mathrm{OH}$ ase to produce $1,25(\mathrm{OH})_{2} \mathrm{D}$. The expression of the VDR and 1-OHase is upregulated when TLR2/1 is stimulated by LPS. This results in an increase in the expression of the VDR and the 1-OHase. The increase production of $1,25(\mathrm{OH})_{2} \mathrm{D}$ increases the nuclear expression of cathelicidin $(\mathrm{CD})$ in the macrophage, which is a cationic peptide that causes the destruction of infective agents including $M$. tuberculosis.

study in hypertensive adults exposed to simulated sunlight 3 times a week for 3 months resulted in an increase in their 25(OH)D levels by more than $150 \%$ and a significant $(6 \mathrm{mmHg})$ reduction in both systolic and diastolic blood pressure (113).

\section{Autocrine production and function of $1,25(\mathrm{OH})_{2} \mathrm{D}$}

Circulating levels of $1,25(\mathrm{OH})_{2} \mathrm{D}$ are very low or undetectable in patients with chronic kidney disease (114). It has been assumed that the kidneys are the sole source of $1,25(\mathrm{OH})_{2} \mathrm{D}$. However, just as most tissues and cells in the body have a VDR, so too do these tissues and cells possess the ability to express CYP27B1. Thus, the skin, prostate, breast, colon, lung, brain, and placenta not only express the VDR but also have the capacity to produce $1,25(\mathrm{OH})_{2} \mathrm{D}$ $(22,24,115,116)$. It is now recognized that $1,25(\mathrm{OH})_{2} \mathrm{D}$ helps control the expression of more than 200 genes $(20-22,24,117)$. It is thought that $1,25(\mathrm{OH})_{2} \mathrm{D}$ maintains cellular health by acting as a sentinel for preventing malignancy $(24,95,96)$ (Figure 5).

Activated macrophages also express CYP27B1 and thus produce $1,25(\mathrm{OH})_{2} \mathrm{D}$. This is the mechanism by which patients with chronic granulomatous diseases such as sarcoidosis and tuberculosis develop a disorder in calcium metabolism that causes hypercalcuria and hypercalcemia $(1,22,24)$. Why macrophages produce $1,25(\mathrm{OH})_{2} \mathrm{D}$ was unknown until Liu et al. (118) reported that activation of TLRs with LPS resulted in the upregulation of the expression of not only VDR but also the CYP27B1 gene. The local production of $1,25(\mathrm{OH})_{2} \mathrm{D}$ induced the expression of the antimicrobial peptide cathelicidin (LL-37), which is thought to be a key factor in the innate immune response when TLR is activated by an infective agent such as Mycobacterium tuberculosis (Figure 5). This remarkable observation explains why patients with TB often do better when placed in a solarium and exposed to sunlight or taken to higher altitudes where the vitamin $\mathrm{D}_{3}$ production in the skin is more efficient (14). This also is the likely reason why African Americans, who are often vitamin D deficient, and children with vitamin D deficiency have increased susceptibility to TB infection (118). This also may explain why it was widely reported that children with rickets often are more prone to infectious diseases, including the common cold virus $(12-14,119)$. 


\section{Conclusion}

Vitamin D-deficiency rickets is a sunlight deficiency disease. The inability to appreciate the beneficial effect of sunlight for health had devastating consequences for both children and adults for more than 300 years. When it was finally realized that exposure to sunlight could prevent and treat rickets, this led to the recommendation that all children be exposed to sensible sunlight to maximize bone health. The fortification of milk with vitamin $\mathrm{D}$ eradicated rickets as a major health problem, and, therefore, it was thought to have been conquered.

Rickets has, however, made an unfortunate comeback (120). The major cause of rickets in the United States is a lack of appreciation that human milk contains very little if any vitamin $\mathrm{D}$ to satisfy the infant's requirement. African American women are often vitamin $\mathrm{D}$ deficient, and women who always wear sun protection and only take a prenatal multivitamin are also at a high risk of vitamin D insufficiency. If they provide breast milk to their infant as the sole source of nutrition, the infant will become vitamin $\mathrm{D}$ deficient. If the infant is not exposed to sunlight or does not receive a vitamin D supplement, the infant will inevitably develop rickets. However, the skeletal manifestations of rickets represent only the tip of the vitamin D deficiency iceberg. Vitamin D deficiency in utero and during the first year of life has devastating consequences and may imprint on the child's life chronic diseases that will shorten his/her life span $(24,57)$. In utero, vitamin D deficiency results in reduced intrauterine long bone growth and slightly shorter gestation (121). This has been linked to increased risk of osteoporosis and fractures later in life $(24,60,61,82,122)$. Children born and raised at latitudes below $35^{\circ}$ for the first 10 years have a $50 \%$ reduced risk of developing multiple sclerosis later in life $(103,104)$. Neonates who are vitamin $\mathrm{D}$ deficient during the first year of life are 2.4-fold more likely to develop type 1 diabetes compared with children who received 2,000 IU of vitamin $\mathrm{D}_{3}$ /day (105). It has been suggested that the increased risk of developing schizophrenia may be initiated in utero and during childhood due to vitamin D deficiency (102). Muscle function, innate immunity, cellular growth and maturation, immunomodulation, insulin secretion, as well as regulation of calcium, phosphorus, and bone metabolism are all affected or controlled by vitamin $\mathrm{D}$. Thus, ensuring that women during pregnancy are vitamin D sufficient and that newborns either be immediately evaluated for their vitamin $\mathrm{D}$ status by measuring $25(\mathrm{OH}) \mathrm{D}$ levels in cord blood or given vitamin $\mathrm{D}$ prophylactically should be a high priority. Vitamin D deficiency should be immediately treated with at least $1,000 \mathrm{IU}$ of vitamin $\mathrm{D}_{2}$ or vitamin $\mathrm{D}_{3}$ /day for the first week of life. Alternatively, a single dose of 200,000 IU of vitamin D should suffice for the first few months of life.

There has been a great fear about causing vitamin $\mathrm{D}$ intoxication in neonates. This resulted from the poorly described outbreak of neonatal hypercalcemia in the 1950s in Great Britain (123), which led to the enactment of laws in Europe forbidding the fortification of dairy products as well as all other products with vitamin D. In 1997 the Institute of Medicine recommended that the AI for infants and children of all ages be $200 \mathrm{IU} / \mathrm{d}$. The same recommendation was made for pregnant and lactating women. The safe upper limit for infants ages $0-12$ months was $1,000 \mathrm{IU} / \mathrm{d}$ and for children older than 1 year of age, 2,000 IU/d. However, it is now obvious based on the historical literature (14-16) as well as the recent literature (23, $24,30,36,81,86,87)$ that these recommendations are inadequate without sensible sun exposure. It is well documented that neonates and children can tolerate a single dose of 200,000 IU of vitamin $\mathrm{D}_{2}$ or vitamin $\mathrm{D}_{3}$ or doses of vitamin $\mathrm{D}$ up to $3,000 \mathrm{IU} / \mathrm{d}$ without any untoward side effects. Indeed 400-1,000 IU/d to maintain serum $25(\mathrm{OH}) \mathrm{D}$ levels between $30-50 \mathrm{ng} / \mathrm{ml}$ should be the goal, just as it is in adults. Infants and children have routinely received 400-2,000 IU vitamin $\mathrm{D}_{2}$ or vitamin $\mathrm{D}_{3}$ /day for the first years of life without any reports of toxicity $(23,80,105,107)$. Typically, doses of more than $50,000 \mathrm{IU} / \mathrm{d}$ of vitamin $\mathrm{D}_{2}$ were found to cause toxicity (12-14).

In Canada, it is recommended that all infants receive $400 \mathrm{IU} / \mathrm{d}$ from birth. This recommendation has been successfully implemented and has not resulted in any reported cases of vitamin D intoxication or hypercalcemia. I believe that the $200 \mathrm{IU}$ of vitamin D that is recommended by the American Academy of Pediatrics is suboptimal (124). This dose may prevent overt rickets but will not prevent vitamin D deficiency.

Hopefully, history will not repeat itself. The widespread concern about any direct sun exposure increasing the risk of the relatively benign and nonlethal squamous and basal cell cancers needs to be put into perspective. It is chronic excessive exposure to sunlight and sunburning experiences during childhood that increases risk of nonmelanoma skin cancer (125). Melanoma, one of the most feared cancers because of its ability to rapidly metastasize before it is obvious to either the patient or physician, has been branded as a sun-induced skin cancer. However, most melanomas occur on the least sun-exposed areas, and it has been reported that occupational exposure to sunlight decreases risk of melanoma (125).

The 30-year campaign to recommend abstinence from sun exposure has not stemmed the increase in skin cancer incidence (125). It is curious that in the 1930s and 1940s, when children were encouraged to be exposed to sunlight and artificial UV radiation to treat rickets, the incidence of skin cancer did not increase. Thus, there needs to be a reevaluation of the beneficial effect of sensible exposure to sunlight as noted by the Australian College of Dermatologists and the Cancer Council Australia, which recommend a balance between avoiding an increase risk of skin cancer and achieving enough UV radiation to maintain adequate vitamin D levels.

\section{Acknowledgments}

This work was supported in part by NIH grants M01RR00533 and AR36963 and the UV Foundation.

Address correspondence to: Michael F. Holick, Boston University School of Medicine, 715 Albany Street, M-1013, Boston, Massachusetts 02118, USA. Phone: (617) 638-4545; Fax: (617) 638-8882; E-mail: mfholick@bu.edu.
1. Holick, M.F. 2005. Vitamin D. In Modern nutrition in health and disease. 10th edition. M. Shils et al., editors. Lippincott Williams \& Wilkins. Baltimore, Maryland, USA. 329-345.

2. Rajakumar, K. 2003. Vitamin D, cod-liver oil, sunlight, and rickets: a historical perspective. Pediatrics. 112: $132-135$

3. Mozolowski, W. 1939. Jedrzej Sniadecki (17681838 ) on the cure of rickets. Nature 143:121-124.
4. Palm, T.A. 1890. The geographical distribution and etiology of rickets. Practitioner. 45:270-342.

5. Huldschinsky, K. 1919. Heilung von Rachitis durch künstliche Höhensonne. Dtsch. Med. Wochenschr. 45:712-713.

6. Huldschinsky, K. 1928. The ultra-violet light treatment of rickets. Alpine Press. New Jersey, USA. 3-19.

7. Hess, A.F., and Unger, L.J. 1921. The cure of infantile rickets by sunlight. JAMA. 77:39-41.
8. Mellanby, T. 1918. The part played by an "accessory factor" in the production of experimental rickets. J. Physiol. 52:11-14

9. McCollum, E.F., Simmonds, N., Becker, J.E., and Shipley, P.G. 1922. Studies on experimental rickets; and experimental demonstration of the existence of a vitamin which promotes calcium deposition. J. Biol. Chem. 53:293-312.

10. Hess, A.F., and Weinstock, M. 1924. Antirachitic 
properties imparted to inert fluids and to green vegetables by ultraviolet irradiation. J. Biol. Chem. 62:301-313.

11. Steenbock, H., and Black, A. 1924. The reduction of growth-promoting and calcifying properties in a ration by exposure to ultraviolet light. J. Biol. Chem. 61:408-422.

12. Hess, A.F. 1929. Rickets including osteomalacia and tetany. Lea \& Febiger. Philadelphia, Pennsylvania, USA. 401-429.

13. Hess, A.F. 1936. Collected writings. Volume 1. Charles C. Thomas. Springfield, Illinois, USA. 669-719.

14. Eliot, M.M., and Park, E.A. 1938. Rickets. In Brennemann's practice of pediatrics. Volume 1. W.F. Prior Company Inc. Hagerstown, Maryland, USA. $1-110$.

15. MacLaughlin, J.A., Anderson, R.R., and Holick, M.F. 1982. Spectral character of sunlight modulates photosynthesis of previtamin $\mathrm{D}_{3}$ and its photoisomers in human skin. Science. 216:1001-1003.

16. Clemens, T.L., Henderson, S.L., Adams, J.S., and Holick, M.F. 1982. Increased skin pigment reduces the capacity of skin to synthesise vitamin $\mathrm{D}_{3}$. Lancet. 1:74-76

17. Matsuoka, L.Y., Ide, L., Wortsman, J., MacLaughlin, J., and Holick, M.F. 1987. Sunscreens suppress cutaneous vitamin $\mathrm{D}_{3}$ synthesis. J. Clin. Endocrinol. Metab. 64:1165-1168.

18. Holick, M.F., MacLaughlin, J.A., and Doppelt, S.H. 1981. Regulation of cutaneous previtamin $\mathrm{D}_{3}$ photosynthesis in man: skin pigment is not an essential regulator. Science. 211:590-593.

19. Webb, A.R., Kline, L., and Holick, M.F. 1988. Influence of season and latitude on the cutaneous synthesis of vitamin $\mathrm{D}_{3}$ : exposure to winter sunlight in Boston and Edmonton will not promote vitamin $\mathrm{D}_{3}$ synthesis in human skin. J. Clin. Endocrinol. Metab. 67:373-378.

20. Holick, M.F. 2004. Vitamin D: importance in the prevention of cancers, type 1 diabetes, heart disease, and osteoporosis. Am. J. Clin. Nutr. 79:362-371.

21. DeLuca, H.F. 2004. Overview of general physiologic features and functions of vitamin D. Am. J. Clin. Nutr. 80(Suppl.):1689S-1696S.

22. Bouillon, R. 2001. Vitamin D: from photosynthesis, metabolism, and action to clinical applications. In Endocrinology. L.J. DeGroot and J.L. Jameson, editors. W.B. Saunders. Philadelphia, Pennsylvania, USA. 1009-1028.

23. Markestad, T., Halvorsen, S., Halvorsen, K.S., Aksnes, L., and Aarskog, D. 1984. Plasma concentrations of vitamin D metabolites before and during treatment of vitamin D deficiency rickets in children. Acta Paediatr. Scand. 73:225-231.

24. Holick, M.F. 2006. High prevalence of vitamin D inadequacy and implications for health. Mayo Clin. Proc. 81:353-373.

25. Christakos, S., Dhawan, P., Liu, Y., Peng, X., and Porta, A. 2003. New insights into the mechanisms of vitamin D action. J. Cell. Biochem. 88:695-705.

26. Khosla, S. 2001. The OPG/RANKL/RANK system. Endocrinology. 142:5050-5055.

27. Brown, E.M., et al. 1993. Cloning and characterization of an extracellular $\mathrm{Ca}^{2+}$-sensing receptor from bovine parathyroid. Nature. 366:575-580.

28. Aiken, C.G.A., Sherwood, R.A., and Lenney, W. 1993. Role of plasma phosphate measurements in detecting rickets of prematurity and in monitoring treatment. Ann. Clin. Biochem. 30:469-475.

29. Gultekin, A., Ozalp, I., Hasanoglu, A., and Unal, A. 1987. Serum-25-hydroxycholecalciferol levels in children and adolescents. Turk. J. Pediatr. 29:155-162.

30. Garabedian, M., and Ben-Mekhbi, H. 1999. Rickets and vitamin D deficiency. In Vitamin D physiology, molecular biology, and clinical applications. M.F. Holick, editor. Humana Press. New Jersey, USA. 273-286.

31. David, L. 1991. Common vitamin $\mathrm{D}_{3}$ deficiency rickets. In Rickets. Nestle nutrition workshop series.
F.H. Glorieux, editor. Raven Press. New York, New York, USA. 107-122.

32. Pettifor, J.M. 2005. Vitamin D deficiency and nutritional rickets in children. In Vitamin D. 2nd edition. D. Feldman, J.W. Pike, and F.H. Glorieux, editors. Elsevier Academic Press. Boston, Massachusetts, USA. 1065-1084.

33. Henderson, J.B., et al. 1987. The importance of limited exposure to ultraviolet radiation and dietary factors in the etiology of Asian rickets: a risk-factor model. Q. J. Med. 63:413-425.

34. Thacher, T.D., et al. 1999. A comparison of calcium, vitamin $\mathrm{D}$, or both for nutritional rickets in Nigerian children. N. Engl. J. Med. 41:563-568.

35. DeLucia, M.C., Mitnick, M.E., and Carpenter, T.O. 2003. Nutritional rickets with normal circulating 25-hydroxyvitamin D: a call for reexamining the role of dietary calcium intake in North American infants. J. Clin. Endocrinol. Metab. 88:3539-3545.

36. Mawer, E.B., Stanbury, S.W., Robinson, M.J., James, J., and Close, C. 1986. Vitamin D nutrition and vitamin D metabolism in the premature human neonate. Clin. Endocrinol. 25:641-649.

37. Lee, J.M., et al. 2006. Vitamin D deficiency in a healthy group of mothers and newborn infants. Clin Pediatr. In press.

38. Sullivan, S.S., Rosen, C.J., Halteman, W.A., Chen, T.C., and Holick, M.F. 2005. Adolescent girls in Maine are at risk for vitamin D insufficiency. J. Am. Diet. Assoc. 105:971-974.

39. Gordon, C.M., DePeter, K.C., Feldman, H.A., Grace, E., and Emans, S.J. 2004. Prevalence of vitamin D deficiency among healthy adolescents. Arch. Pediatr. Adolesc. Med. 158:531-537.

40. Looker, A.C., Dawson-Hughes, B., Calvo, M.S. Gunter, E.W., and Sahyoun, N.R. 2002. Serum 25hydroxyvitamin D status of adolescents and adults in two seasonal subpopulations from NHANES III. Bone. 30:771-777.

41. Iqbal, S.J., Kaddam, I., Wassif, W., Nichol, F., and Walls, J. 1994. Continuing clinically severe vitamin $\mathrm{D}$ deficiency in Asians in the UK (Leicester). Postgrad. Med. J. 70:708-714.

42. Binet, A., and Kooh, S.W. 1996. Persistence of vitamin D-deficiency rickets in Toronto in the 1990s. Can. J Public Health. 87:227-230.

43. Lamberg-Allardt, C., Ojaniemi, R., Ahola, M., and Räsänen, L. 1984. The vitamin D intake of children and adolescents in Finland. Hum. Nutr. Appl. Nutr. 38A:377-382.

44. Hoogenboezem, H.J., et al. 1989. Vitamin D metabolism in breast-fed infants and their mothers. Pediatr. Res. 31:623-628.

45. Calvo, M.S., Whiting, S.J., and Barton, C.N. 2004. Vitamin D fortification in the United States and Canada: current status and data needs. Am. J. Clin. Nutr. 80(Suppl.):1710S-1716S.

46. Bhattacharyya, A.K. 1992. Nutritional rickets in the tropics. In Nutritional triggers for health and in disease. A.P. Simopoulos, editor. Kruger. Basel, Switzerland. 141-197.

47. Taha, S.A., Dost, S.M., and Sedrani, H. 1984. 25Hydroxyvitamin D and total calcium: extraordinarily low plasma concentrations in Saudi mothers and their neonates. Pediatr. Res. 18:739-741.

48. Marwaha, R.K., et al. 2005. Vitamin D and bone mineral density status of healthy schoolchildren in northern India. Am. J. Clin. Nutr. 82:477-482.

49. Arthur, A. 2000. Rickets in the welfare state. $N Z$ Med. J. 113:374-377.

50. Nehama, H., et al. 1987. Seasonal variation in paired maternal newborn serum 25-hydroxyvitamin D and 24,25-dihydroxyvitamin D concentrations in Israel. Isr. J. Med. Sci. 23:274-277.

51. Lawson, D.E.M., et al. 1987. Aetiology of rickets in Egyptian children. Hum. Nutr. Clin. Nutr. 41C: $199-208$

52. Leung, S.S.F., Lui, S., and Swaminathan, R. 1989.
Vitamin D status of Hong Kong Chinese infants. Acta Paediatr. Scand. 413:303-306.

53. Feliciano, E.S., et al. 1994. Seasonal and geographical variations in the growth rate of infants in China receiving increasing dosages of vitamin D supplements. J. Trop. Pediatr. 40:162-165.

54. Elzouki, A.Y., Markestad, T., Elgarrah, M., Elhoni, N., and Aksnes, L. 1989. Serum concentrations of vitamin D metabolites in rachitic Libyan children. J. Pediatr. Gastroenterol. Nutr. 9:507-512.

55. El-Hajj Fuleihan, G., et al. 2001. Hypovitaminosis $\mathrm{D}$ in healthy school children. Pediatrics. 107:E53.

56. Docio, S., et al. 1998. Seasonal deficiency of vitamin D in children: a potential target for osteoporosis-preventing strategies? J. Bone Miner. Res. 13:544-548.

57. McGrath, J.J., Kimlin, M.G., Saha, S., Eyles, D.W., and Parisi, A.V. 2001. Vitamin D insufficiency in south-east Queensland. Med. J. Aust. 174:150-151.

58. Hayward, I., Stein, M.T., and Gibson, M.I. 1987. Nutritional rickets in San Diego. Am. J. Dis. Child. 141:1060-1062.

59. Stein, E.M., et al. 2006. Serum 25-hydroxyvitamin D concentrations in girls aged 4-8 y living in the southeastern United States. Am. J. Clin. Nutr. 83:75-81.

60. Tylavsky, F.A., Ryder, K.A., Lyytikainen, A., and Cheng, S. 2005. Vitamin D, parathyroid hormone, and bone mass in adolescents. J. Nutr. 135:2735S-2738S.

61. Cooper, C., Javaid, K., Westlake, S., Harvey, N., and Dennison, E. 2005. Developmental origins of osteoporotic fracture: the role of maternal vitamin D insufficiency. J. Nutr. 135:2728S-2734S.

62. Casella, S.J., Reiner, B.J., Chen, T.C., and Holick, M.F. 1994. A possible defect in 25 -hydroxylation as a cause of rickets. J. Pediatr. 124:929-932.

63. Gascon-Barre, M. 2005. The vitamin D 25-hydroxylase. In Vitamin D. 2nd edition. D. Feldman, J.W. Pike, and F.H. Glorieux, editors. Elsevier Academic Press. Boston, Massachusetts, USA. 47-68.

64. Fraser, D., et al. 1973. Pathogenesis of hereditary vitamin-D-dependent rickets. An inborn error of vitamin $\mathrm{D}$ metabolism involving defective conversion of 25-hydroxyvitamin D to 1 alpha,25-dihydroxyvitamin D. N. Engl. J. Med. 289:817-822.

65. Kitanaka, S., et al. 1998. Inactivating mutations in the human 25-hydroxyvitamin $\mathrm{D}_{3}$ 1alpha- hydroxylase gene in patients with pseudovitamin D-deficient rickets. N. Engl. J. Med. 338:653-661.

66. Malloy, P.J., Pike, J.W., and Feldman, D. 2005. Hereditary 1,25-dihydroxyvitamin D resistant rickets. In Vitamin D. 2nd edition. D. Feldman, J.W. Pike, and F.H. Glorieux, editors. Elsevier Academic Press. Boston, Massachusetts, USA. 1207-1237.

67. Brooks, M.H., et al. 1978. Vitamin-D-dependent rickets type II: resistance of target organs to 1,25 dihydroxyvitamin D. N. Engl. J. Med. 298:996-999.

68. Chen, H., Hewison, M., Hu, B., and Adams, J.S. 2003. Heterogeneous nuclear ribonucleoprotein (hnRNP) binding to hormone response elements: a cause of vitamin D resistance. Proc. Natl. Acad. Sci. U. S. A. 100:6109-6114.

69. Balsan, S., et al. 1986. Long-term nocturnal calcium infusions can cure rickets and promote normal mineralization in heredity resistance to 1,25 -dihydroxyvitamin D. J. Clin. Invest. 77:1661-1667.

70. Drezner, M.K. 2005. Clinical disorders of phosphate homeostasis. In Vitamin D. 2nd edition. D. Feldman, J.W. Pike, and F.H. Glorieux, editors. Elsevier Academic Press. Boston, Massachusetts, USA. 1159-1187.

71. Econs, M.J. 2005. Disorders of phosphate metabolism: autosomal dominant hypophosphatemic rickets, tumor induced osteomalacia, fibrous dysplasia, and the pathophsiological relevance of FGF23. In Vitamin D. 2nd edition. D. Feldman, J.W. Pike, F. H. Glorieux, editors. Elsevier Academic Press. Boston, Massachusetts, USA. 1189-1195.

72. Portale, A.A., Halloran, B.P., Murphy, M.M., and 
Morris, R.C. 1986. Oral intake phosphorus can determine the serum concentration of 1,25-dihyroxyvitamin $\mathrm{D}$ by determining its production rate in humans. J. Clin. Invest. 77:7-12.

73. Kolek, O.I., et al. 2005. 1,25-Dihydroxyvitmin $\mathrm{D}_{3}$ upregulates FGF23 gene expression in bone; the final link in a renal-gastrointestinal-skeletal axis that controls phosphate transport. Am. J. Physiol. Gastrointest. Liver Physiol. 289:1036-1104.

74. Perwad, F., et al. 2005. Dietary and serum phosphorus regulate fibroblast growth factor 23 expression and 1,25-dihydroxyvitamin D metabolism in mice. Endocrinology. 146:5358-5364.

75. Shimada, T., et al. 2001. Cloning and characterization of FGF23 as a causative factor of tumorinduced osteomalacia. Proc. Natl. Acad. Sci. U. S. A. 98:6500-6505.

76. Yeung, S.J., McCutcheon, I.E., Schultz, P., and Gagel, R.F. 2000. Use of long-term intravenous phosphate infusion in the palliative treatment of tumor-induced osteomalacia. J. Clin. Endocrinol. Metab. 85:549-555.

77. Whyte, M.P., Podgornik, M.N., Wollberg, V.A., Eddy, M.C., and McAlister, W.H. 2001. Pseudo-(tumorinduced) rickets. J. Bone Miner. Res. 16:1564-1571.

78. Ward, L.M., et al. 2004. Resolution of severe, adolescent-onset hypophosphatemic rickets following resection of an FGF-23-producting tumour of the distal ulna. Bone. 34:905-911.

79. Roth, D.E., et al. 2005. Are national vitamin D guidelines sufficient to maintain adequate blood levels in children? Can. J. Public Health. 96:443-449.

80. Koo, W., et al. 1995. Effect of three levels of vitamin $\mathrm{D}$ intake in preterm infants receiving high mineral-containing milk. J. Pediatr. Gastroenterol. Nutr. 21:182-189.

81. Salle, B.L., et al. 1982. Early oral administration of vitamin $\mathrm{D}$ and its metabolites in premature neonates, effect on mineral homeostasis. Pediatr Res. 16:75-78.

82. Holick, M.F. 2005. The vitamin D epidemic and its health consequences. J. Nutr. 135:2739S-2748S.

83. Dawson-Hughes, B., et al. 2005. Estimates of optimal vitamin D status [editorial]. Osteoporos. Int 16:713-716

84. Vieth, R. 2004. Why the optimal requirement for vitamin $\mathrm{D}_{3}$ is probably much higher than what is officially recommended for adults. J. Steroid Biochem. Mol. Biol. 88-89:575-579.

85. Standing Committee on the Scientific Evaluation of Dietary Reference Intakes. 1997. Vitamin D. In Dietary reference intakes. Chapter 7 . National Academy Press. Washington, DC, USA. 250-287.

86. Shah, B.R., and Finberg, L. 1994. Single-dose therapy for nutritional vitamin $\mathrm{D}$ deficiency rickets: a preferred method. J. Pediatr. 125:487-490.

87. Hollis, B.W., and Wagner, C.L. 2004. Assessment of dietary vitamin $\mathrm{D}$ requirements during pregnancy and lactation. Am. J. Clin. Nutr. 79:717-726.

88. Aris, R.M., et al. 2005. Guide to bone health and disease in cystic fibrosis. J. Clin. Endocrinol. Metab. 90:1888-1896.

89. Brot, C., et al. 2001. Vitamin D status and its adequacy in healthy Danish perimenopausal women: relationships to dietary intake, sun exposure and serum parathyroid hormone. Br. J. Nutr. 86:1-11.

90. Hollis, B.W., and Wagner, C.L. 2004. Vitamin D requirements during lactation: high-dose maternal supplementation as therapy to prevent hypovitaminosis D for both the mother and the nursing infant. Am. J. Clin. Nutr. 80(Suppl. 6):1752S-1758S.

91. Simpson, R.U., Thomas, G.A., and Arnold, A.J. 1985. Identification of 1,25-dihydroxyvitamin D, receptors and activities in muscle. J. Biol. Chem. 260:8882-8891.

92. Bischoff-Ferrari, H.A., et al. 2004. Effect of vitamin D on falls: a meta-analysis. JAMA. 291:1999-2006.

93. Black, P.N., and Scragg, R. 2005. Relationship between serum 25-hydroxyvitamin $\mathrm{D}$ and pulmonary function in the Third National Health and Nutrition Examination Survey. Chest. 128:3792-3798.

94. Camargo, C.A., Jr., et al. 2006. Prospective study of maternal intake of vitamin D during pregnancy and risk of wheezing illness in children at age 2 years [abstract]. J. Allergy Clin. Immunol. 117:721-722.

95. Spina, C., et al. 2005. Colon cancer and solar ultraviolet $B$ radiation and prevention and treatment of colon cancer in mice with vitamin D and its Gemin analogs. J. Steroid Biochem. Mol. Biol. 97:111-120.

96. Feldman, D., Zhao, X.Y., and Krishnan, A.V. 2000 Editorial/mini-review: vitamin D and prostate cancer. Endocrinology. 141:5-9.

97. Grant, W.B. 2002. An estimate of premature cancer mortality in the U.S. due to inadequate doses of solar ultraviolet-B radiation. Cancer 94:1867-1875.

98. Grant, W.B., and Holick, M.F. 2005. Benefits and requirements of vitamin $\mathrm{D}$ for optimal health: a review. Altern. Med. Rev. 10:94-111.

99. Gorham, E.D., et al. 2005. Vitamin D and prevention of colorectal cancer. J. Steroid Biochem. Mol. Biol. 97:179-194.

100.Chang, E.T., et al. 2005. Family history of hematopoietic malignancy and risk of lymphoma. J. Natl. Cancer Inst. 97:1466-1474.

101. Berwick, M., et al. 2005. Sun exposure and mortality from melanoma. J. Natl. Cancer Inst 97:195-199.

102.McGrath, J. 2001. Does 'imprinting' with low prenatal vitamin $\mathrm{D}$ contribute to the risk of various adult disorders? Med. Hypotheses. 56:367-371.

103.Hernán, M.A., Olek, M.J., and Ascherio, A. 1999. Geographic variation of MS incidence in two prospective studies of US women. Neurology. 51:1711-1718.

104.Ponsonby, A.L., McMichael, A., and van der Mei, I. 2002. Ultraviolet radiation and autoimmune disease: insights from epidemiological research. Toxicology. 181-182:71-78.

105.Hypponen, E., Laara, E., Jarvelin, M.-R., and Virtanen, S.M. 2001. Intake of vitamin D and risk of type 1 diabetes: a birth-cohort study. Lancet. 358:1500-1503.

106.Cantorna, M.T., Zhu, Y., Froicu, M., and Wittke, A. 2004. Vitamin D status, 1,25-dihydroxyvitamin $\mathrm{D}_{3}$, and the immune system. Am. J. Clin. Nutr. 80(Suppl.): 1717S-1720S.

107. Stene, L.C., Joner, G., and Norwegian Childhood Diabetes Study Group. 2003. Use of cod liver oil during the first year of life is associated with lower risk of childhood-onset type 1 diabetes: a large, population-based, case-control study. Am. J. Clin. Nutr. 78:1128-1134.

108. Mathieu, C., and Adorini, L. 2002. The coming of age of 1,25-dihydroxyvitamin $\mathrm{D}_{3}$ analogs as immunomodulatory agents. Trends Mol. Med. 8:174-179.

109.Chiu, K.C., Chu, A., Go, V.L.W., and Saad, M.F.
2004. Hypovitaminosis D is associated with insulin resistance and $\beta$ cell dysfunction. Am. J. Clin. Nutr. 79:820-825.

110. Rostand, S.G. 1979. Ultraviolet light may contribute to geographic and racial blood pressure differences. Hypertension. 30:150-156.

111.Zittermann, A., et al. 2003. Low vitamin D status: a contributing factor in the pathogenesis of congestive heart failure? J. Am. Coll. Cardiol. 41:105-112.

112.Li, Y., et al. 2002. 1,25-dihydroxyvitamin $\mathrm{D}_{3}$ is a negative endocrine regulator of the renin-angiotensin system. J. Clin. Invest. 110:229-238. doi:10.1172/ JCI200215219.

113.Krause, R., Buhring, M., Hopfenmuller, W., Holick, M.F., and Sharma, A.M. 1998. Ultraviolet B and blood pressure. Lancet. 352:709-710.

114.Holick, M.F., 2005. Vitamin D for health and in chronic kidney disease. Semin. Dial. 18:266-275.

115.Bikle, D.D. 2005. Vitamin D: role in skin and hair. In Vitamin D. 2nd edition. D. Feldman, J.W. Pike, and F.H. Glorieux, editors. Elsevier Academic Press. Boston, Massachusetts, USA. 609-630.

116.Schwartz, G.G., Whitlatch, L.W., Chen, T.C. Lokeshwar, B.L., and Holick, M.F. 1998. Human prostate cells synthesize 1,25-dihydroxyvitamin $\mathrm{D}_{3}$ from 25-hydroxyvitamin $\mathrm{D}_{3}$. Cancer Epidemiol. Biomarkers Prev. 7:391-395.

117. Rachez, C., and Freedman, L.P. 2000. Mechanisms of gene regulation by vitamin $\mathrm{D}_{3}$ receptor: a network of coactivator interactions. Gene. 246:9-21.

118.Liu, P.T., et al. 2006. Toll-like receptor triggering of a vitamin D-mediated human antimicrobial response. Science. 3:1770-1773.

119.Krause, R., et al. 1999. Suberythemal UV-irradiation increases immunological capacity in children with frequent cold. In Biological effects of light 1998: proceedings of a symposium, Basel, Switzerland, November 1-3, 1998. Basel, Switzerland. M.F. Holick and E.G. Jung, editors. Kluwer Academic Publishers. Boston, Massachusetts, USA. 49-51.

120.Kreiter, S.R., et al. 2000. Nutritional rickets in African American breast-fed infants. J. Pediatr. 137:153-157.

121.Morley, R., Carlin, J.B., Pasco, J.A., and Wark, J.D. 2006. Maternal 25-hydroxyvitamin D and parathyroid hormone concentrations and offspring birth size. J. Clin. Endocrinol. Metab. 91:906-912.

122.Jones, G., and Dwyer, T. 1998. Bone mass in prepubertal children: gender differences and the role of physical activity and sunlight exposure. J. Clin. Endocrinol. Metab. 83:4274-4279.

123. British Pediatric Association. 1956. Hypercalcemia in infants and vitamin D. Br. Med. J. 2:149-151.

124.Gartner, L.M., Greer, F.R., Section on Breastfeeding, and Committee on Nutrition, American Academy of Pediatrics. 2003. Prevention of rickets and vitamin D deficiency: new guidelines for vitamin D intake. Pediatrics. 111:908-910.

125.Kennedy, C., Basidik, C.D., Willemze, R., de Gruiil, F.R., and Bavinck, J.N. 2003. The influence of painful sunburns and lifetime of sun exposure on the risk of actinic keratoses, seborrheic warts, melanocytic nevi, atypical nevi, and skin cancer. J. Invest. Dermatol. 120:1087-1093.

126. Gamgee, K.M.L. 1927. The artificial light treatment of children in rickets, anaemia \& malnutrition. P.B. Hoeber Inc. New York, New York, USA. 172 pp. 